\title{
Early insulin therapy prevents beta cell loss in a mouse model for permanent neonatal diabetes (Munich Ins2 ${ }^{\text {C95S }}$ )
}

\author{
S. Kautz • L. van Bürck • M. Schuster • E. Wolf • \\ R. Wanke • N. Herbach
}

Received: 24 March 2011 / Accepted: 10 October 2011 /Published online: 18 November 2011

(C) Springer-Verlag 2011

\begin{abstract}
Aims Heterozygous male Munich Ins2 ${ }^{\mathrm{C} 95 \mathrm{~S}}$ mutant mice, a model for permanent neonatal diabetes mellitus, demonstrate a progressive diabetic phenotype with severe loss of functional beta cell mass. The aim of this study was to investigate the influence of early insulin treatment on glucose homeostasis and beta cell destruction in male Munich $I n s 2^{\text {C95S }}$ mutants. Methods One group of male Ins $2^{\mathrm{C} 95 \mathrm{~S}}$ mutants was treated with subcutaneous insulin pellets, as soon as blood glucose levels began to rise; placebo-treated mutants and wild-type mice served as controls. An additional group of mutant mice received a sodium-dependent glucose transporter 2 (SGLT2) inhibitor (AVE2268) via rodent chow.
\end{abstract}

Electronic supplementary material The online version of this article (doi:10.1007/s00125-011-2362-7) contains peer-reviewed but unedited supplementary material, which is available to authorised users.

S. Kautz $\cdot$ L. van Bürck $\cdot$ M. Schuster $\cdot$ R. Wanke

N. Herbach $(\bowtie)$

Institute of Veterinary Pathology,

Ludwig-Maximilians-Universität München,

Veterinärstr. 13,

80539 Munich, Germany

e-mail: herbach@patho.vetmed.uni-muenchen.de

L. van Bürck

Diabetes Zentrum der LMU, Medizinische Klinik Innenstadt,

Ludwig-Maximilians-Universität München,

Munich, Germany

E. Wolf

Institute of Molecular Animal Breeding and Biotechnology,

Ludwig-Maximilians-Universität München,

Munich, Germany

E. Wolf

Laboratory for Functional Genome Analysis (LAFUGA),

Gene Center, Ludwig-Maximilians-Universität München,

Munich, Germany
Results Insulin treatment normalised blood glucose concentrations, improved oral glucose tolerance, preserved insulin sensitivity and inhibited oxidative stress of Munich $\operatorname{Ins} 2^{\mathrm{C} 95 \mathrm{~S}}$ mutant mice. Pancreatic C-peptide content, as well as total beta cell and isolated beta cell volumes, of insulin-treated mutant mice were higher than those of placebo-treated mutants. In addition, alpha cell dysfunction and hyperplasia of non-beta cells were completely normalised in insulintreated mutant mice. Treatment with the SGLT2 inhibitor lowered blood glucose, improved glucose tolerance and normalised insulin sensitivity as well as oxidative stress of Ins $2^{\mathrm{C} 95 \mathrm{~S}}$ mutants. The abundance of the endoplasmic reticulum (ER) stress markers binding Ig protein (BiP) and phosphorylated eukaryotic translation initiation factor 2 alpha (P-eIF $2 \alpha$ ) was significantly increased in the islets of mutants, before onset of hyperglycaemia, vs wild-type mice. Conclusions We conclude that early insulin treatment protects Munich Ins $2^{\mathrm{C} 95 \mathrm{~S}}$ mutant mice from insulin resistance, alpha cell hyperfunction, beta cell loss and hyperplasia of non-beta cells, some well-known features of human diabetes mellitus. Therefore, insulin treatment may be considered early for human patients harbouring INS mutations.

Keywords ER stress · Insulin secretion in vivo · Insulin sensitivity and resistance $\cdot$ Insulin therapy Islet degeneration and damage $\cdot$ Mouse $\cdot$ Oxidative stress

$\begin{array}{ll}\text { Abbreviations } \\ \text { BiP } & \text { Binding Ig protein } \\ \text { BrdU } & \text { Bromodeoxyuridine } \\ \text { CHOP } & \text { C/EBP homologous protein } \\ \text { ER } & \text { Endoplasmic reticulum } \\ \text { ITT } & \text { Insulin tolerance test } \\ \text { MDA } & \text { Malondialdehyde } \\ \text { PCNA } & \text { Proliferating cell nuclear antigen }\end{array}$


P-eIF2 $\alpha \quad$ Phosphorylated eukaryotic translation initiation factor 2 alpha

PNDM

ROS

SGLT2

Permanent neonatal diabetes mellitus

Reactive oxygen species

Sodium-dependent glucose transporter 2

\section{Introduction}

Permanent neonatal diabetes mellitus (PNDM) is a specific type of diabetes mellitus that may result from mutations in different genes, including INS [1]. In patients diagnosed at less than 6 months of age, INS mutations are the second most common cause of PNDM [2]. Some of the identified mutations in INS are associated with defective insulin secretion, endoplasmic reticulum (ER) stress, and sometimes apoptosis of beta cells [3, 4]. The pathogenic mechanisms leading to PNDM depend on the mutation: recessive INS mutations result in reduced insulin synthesis and dominant mutations lead to proinsulin misfolding and ER stress [5]. Misfolded mutant insulin is frequently retained in the ER, is ineffectively secreted and perturbs production of native insulin [4, 6-9]. The pathogenesis of ER stress and its consequences for beta cells is poorly understood to date. Insulin misfolding may lead to increased ER sulfhydryl oxidation, thereby creating increased levels of reactive oxygen species (ROS). The folding of native insulin and other proteins may also be disturbed as a result of the blocking of oxidative pathways $[6,8]$. Accumulation of misfolded proteins in the ER causes activation of the unfolded protein response and increases ER-associated degradation $[4,6]$. In patients that are at risk of developing monogenic diabetes, such as PNDM, genetic testing offers the opportunity for early medical intervention [1], which may help to prevent apoptotic beta cell death that might be triggered by the expression of mutant insulin [6]. New treatment strategies, addressing cellular stressassociated proteins and pathways that are induced by the expression of mutant insulin, may also help to preserve beta cell function and survival [7,8].

Munich $\operatorname{Ins} 2^{\mathrm{C} 95 \mathrm{~S}}$ mutant mice exhibit a point mutation in the Ins 2 gene $\left(\mathrm{C}^{\mathrm{A} 6} \mathrm{~S} / \mathrm{C} 95 \mathrm{~S}\right)$, leading to the loss of the A6-A11 intrachain disulfide bond of insulin 2 [10]. Heterozygous male mutants demonstrate a progressive diabetic phenotype, with severe hyperglycaemia, development of insulin resistance and profound loss of beta cell mass, and are thus an ideal model to systematically evaluate the consequences of insulin therapy on disease progression [10].

The aim of the present study was to analyse the effects of early insulin therapy on the development of insulin resistance, oxidative stress, ER stress and beta cell loss in Munich $\operatorname{Ins} 2^{\mathrm{C} 95 \mathrm{~S}}$ mutant mice in order to provide new insights into improving the care and treatment of humans harbouring INS mutations.

\section{Methods}

Animals All animal experiments were carried out following the principles of laboratory animal care and were approved by the responsible animal welfare authority (Regierung von Oberbayern, AZ 55.2-1-54-2531-94-07).

Munich Ins $2^{\mathrm{C} 95 \mathrm{~S}}$ mutant mice were established within the Munich $N$-ethyl- $N$-nitrosourea (ENU) mouse mutagenesis project $[10,11]$. At 21 days of age, male heterozygous and homozygous mutants and wild-type mice were investigated. All other investigations included insulin-, AVE2268- and placebo-treated heterozygous male mutants as well as placebo-treated wild-type males.

Insulin treatment As soon as randomly fed blood glucose levels of mutant mice rose above $11.2 \mathrm{mmol} / 1$ ( $\sim 32$ days of age), insulin or placebo pellets (Linbits, Linshin, Toronto, ON, Canada) were applied subcutaneously under general anaesthesia. One group of mutants was treated with insulin pellets, the other mutant and wild-type mice were supplied with placebo pellets.

SGLT2 inhibitor treatment Treatment with a sodiumdependent glucose transporter 2 (SGLT2) inhibitor (AVE2268 [12], sanofi-aventis, Frankfurt, Germany) was initiated at a mean age of $32(n=6)$ and 70 days $(n=8)$. Male mutants were treated with $0.15 \%$ (wt/wt) AVE2268 mixed with their diet, resulting in a daily intake of $300 \mathrm{mg} \mathrm{kg}^{-1}$ day $^{-1}$.

Body weight Randomly fed body weights were determined at the age of $21,31,50,100$ and 150 days to the nearest $0.1 \mathrm{~g}$.

Blood glucose and serum variables At 21 days of age, blood glucose levels of wild-type mice and heterozygous and homozygous mutants were determined using a blood glucose analyser (SUPER GL, Hitado, Möhnesee, Germany) and serum proinsulin and C-peptide II concentrations were determined by Rat/Mouse Proinsulin ELISA (Mercodia, Uppsala, Sweden) and Mouse C-peptide II ELISA (Kamiya, Seattle, WA, USA), respectively. Subsequently, randomly fed blood glucose levels of insulin-, AVE2268- or placebo-treated animals were measured at weekly intervals. Data from 21-, 31-, 60-, 100-, and 135- or 160-day-old mice are shown.

OGTTs were performed [10] at the age of $45,85,100$ and 150 days. Serum C-peptide concentrations were analysed, randomly fed $(0 \mathrm{~min})$ and $10 \mathrm{~min}$ after glucose 
application, using a rat C-peptide RIA kit (Millipore, St Charles, MO, USA).

At the age of 100 days, randomly fed proinsulin and glucagon concentrations were determined using a rat/mouse proinsulin ELISA kit (Mercodia) and a glucagon RIA kit (Millipore), respectively.

Serum lipid peroxidation Lipid peroxidation in the serum of 100- and 140-day-old mice was analysed using a TBARS assay kit (Cayman Chemical, Ann Arbor, MI, USA). Data are presented as malondialdehyde (MDA) equivalents.

Intraperitoneal insulin and placebo-insulin tolerance test Intraperitoneal insulin tolerance tests (ITTs) were carried out with randomly fed mice at the age of 50, 100 and 150 days as described [13]. An intraperitoneal placebo-ITT was performed with 150 -day-old mice, using $0.9 \%$ (wt/vol.) $\mathrm{NaCl}$ solution instead of insulin.

Pancreatic C-peptide-, C-peptide II- and proinsulin-toprotein ratio Pancreases of 21- and 100-day-old mice were homogenised in $2 \mathrm{~mol} / \mathrm{l}$ acetic acid as described previously [14]. Pancreatic C-peptide II and proinsulin concentrations of 21-day-old heterozygous and homozygous mutants as well as wild-type mice, and pancreatic C-peptide and proinsulin of insulin- or placebo-treated mice were determined as described above. Pancreatic protein content was analysed spectrophotometrically (NanoDrop ND-1000, PeqLab Biotechnologie, Erlangen, Germany).

Western blot analyses of isolated islets At 18 days of age, animals were perfused via orthograde vascular perfusion with neutral red, and stained pancreatic islets were isolated and subjected to SDS-PAGE as described previously [13]. Separated proteins were blotted onto a nitrocellulose membrane and assayed for the following ER stress markers: binding Ig protein $(\mathrm{BiP}) / 78 \mathrm{kDa}$ glucose-regulated protein (Grp78) (Stressgen, Victoria, BC, Canada; diluted 1:10,000); C/EBP homologous protein (CHOP)/growth arrest and DNA damage inducible protein 153 (GADD153) (Santa Cruz Biotechnology, Santa Cruz, CA, USA; 1:500) and phosphorylated eukaryotic translation initiation factor $2 \alpha$ (P-eIF2 $\alpha$ ) (Cell Signaling, Danvers, MA, USA; $1: 1,000$ ). In addition, islet-cell replication (mouse anti-proliferating cell nuclear antigen (PCNA), Abcam, Cambridge, UK, $1: 1,000$ ) and apoptosis (rabbit anti-cleaved caspase 3, Cell Signaling, 1:1,000) were determined; actin served as the loading control (Millipore, 1:10,000). Immunoblots were developed using the LumiGlo chemiluminescence reagents (Cell Signaling). The optical densities of bands were determined using ImageJ 1.41o (NIH 2004).
Pancreas preparation Quantitative stereological analyses of the pancreas were performed at 160 days of age. Ninety minutes before being killed, $300 \mu \mathrm{l}$ of a $10 \mathrm{mmol} /$ 1 bromodeoxyuridine (BrdU) solution (Roche, Mannheim, Germany) per mouse was injected intraperitoneally. Tissue was fixed for histology by orthograde vascular perfusion using $4 \%$ (wt/vol.) paraformaldehyde in $0.05 \mathrm{~mol} / \mathrm{l}$ cacodylate buffer $\left(60 \mathrm{mmHg}, 5 \mathrm{~min}, 37^{\circ} \mathrm{C}\right)$. The pancreas was cut into slices of $1 \mathrm{~mm}$ thickness, routinely processed and embedded in paraffin [15].

Immunohistochemistry Immunohistochemistry for beta cells and non-beta cells has been described previously [15]. Replicating and apoptotic beta cells were identified via double immunohistochemistry for insulin- and BrdU- or TUNEL-positive cells, respectively. An alkaline phosphatase conjugated goat anti-guinea pig IgG (Southern Biotech, Birmingham, AL, USA; 1:100) was used to visualise insulin positive cells. Rat anti-human BrdU antibody (Roche; 1:50) and horseradish peroxidase conjugated rabbit anti-rat antibody (DAKO, Hamburg, Germany; 1:50) were used to reveal BrdU-positive cells. TUNEL staining was performed with the Apop Tag Plus peroxidase in situ apoptosis detection kit (Millipore).

Quantitative stereological analyses The pancreases of 160day-old mice were examined, with unbiased quantitative stereological methods, using the Videoplan image analysing system (Zeiss-Kontron, Eching, Germany) as previously described $[10,15,16]$ with minor modifications. Since beta cells of placebo-treated mutants demonstrate a poor staining intensity using immunohistochemistry for insulin [10], the volume densities and total volumes of beta cells were calculated by subtracting the non-beta cell and capillary areas from the total islet area in sections simultaneously immunostained for glucagon, somatostatin and pancreatic polypeptide, to avoid underestimation of degranulated beta cells. The equations used for calculations are shown in electronic supplementary material (ESM) Table 1.

Statistical analysis and data presentation Statistical analyses were performed using one-way ANOVA and the least significant difference (LSD) test, except when comparing the results of insulin vs placebo-insulin tolerance tests and western blot analyses, where a paired or unpaired Student's $t$ test was used, respectively (PASW Statistics 17.0, IBM Deutschland, München, Germany). Serum C-peptide concentrations, and pancreatic Cpeptide- and proinsulin-to-protein ratios, were logarithmised $\left(\log _{e}\right)$ for statistical analyses. $p$ values $<0.05$ were considered significant. Data are presented as means \pm SEM if not stated otherwise. 


\section{Results}

Body weight Body weight gain from 21 to 100 days of age was similar in all groups investigated. At 160 days of age, placebo-treated Munich $\operatorname{Ins} 2^{\mathrm{C} 95 \mathrm{~S}}$ mutant mice demonstrated lower body weights compared with wildtype mice (Table 1).

Blood glucose Blood glucose concentrations of 21-day-old homozygous mutants were significantly higher than those of heterozygous Munich $\operatorname{Ins} 2^{\mathrm{C} 95 \mathrm{~S}}$ mutant and wild-type mice $(16.5 \pm 1.2$ vs $7.7 \pm 0.4$ vs $6.3 \pm 0.2 \mathrm{mmol} / \mathrm{l})$. From 60 days of age onwards, insulin-treated mutants generally displayed normoglycaemia, whereas placebo-treated mutant mice demonstrated a severe progressive diabetic phenotype (Fig. 1a). Blood glucose of 60-, 100- and 135-day-old AVE2268-treated mutants was significantly higher than in insulin-treated mutants and wild-type mice but significantly lower than in placebo-treated mutants (ESM Fig. 1a).

During OGTT, blood glucose concentrations and the corresponding AUCs of insulin-treated mutants were similar to those of wild-type mice (Fig. 1b). The decrease in blood glucose concentration following glucose application was delayed in insulin-treated $\operatorname{Ins} 2^{\mathrm{C} 95 \mathrm{~S}}$ mutant mice compared with wild-type mice, but the delay was not as pronounced as in placebo-treated mutants (Fig. 1c). AVE2268-treated mutants at 100 days of age showed significantly lower blood glucose levels at all time points during OGTT and a lower AUC compared with placebotreated mutants, and significantly higher glucose levels and AUC than insulin-treated mutants and wild-type mice (ESM Fig. 1b,c). These data clearly show that insulin treatment of Ins $2^{\mathrm{C} 95 \mathrm{~S}}$ mutant mice normalised glucose homeostasis and that treatment with the SGLT2 inhibitor largely reduced hyperglycaemia.

Serum variables Serum proinsulin and C-peptide II were determined in order to show whether mutant proinsulin $2^{\mathrm{C} 95 \mathrm{~S}}$ is processed and whether insulin 2 may be secreted.

Table 1 Body weights of randomly fed mice (g)

\begin{tabular}{lllllll}
\hline $\begin{array}{l}\text { Treatment } \\
\text { group }\end{array}$ & $n$ & \multicolumn{5}{l}{ Age (days) } \\
\cline { 3 - 7 } & & 21 & 31 & 50 & 100 & 160 \\
\hline $\mathrm{wt}, \mathrm{pl}$ & 12 & $8.2 \pm 1.3$ & $14.3 \pm 2.2$ & $20.8 \pm 1.6$ & $26.0 \pm 1.7$ & $29.6 \pm 2.1$ \\
$\mathrm{mt}, \mathrm{ins}$ & $\geq 11$ & $7.9 \pm 0.9$ & $13.3 \pm 1.7$ & $20.0 \pm 1.3$ & $25.4 \pm 1.1$ & $28.7 \pm 1.3$ \\
$\mathrm{mt}, \mathrm{pl}$ & $\geq 9$ & $7.6 \pm 2.0$ & $13.4 \pm 1.1$ & $20.0 \pm 1.5$ & $25.0 \pm 1.0$ & $27.5 \pm 1.4^{*}$
\end{tabular}

Data are means \pm SD

wt, pl: wild-type, placebo-treated; $\mathrm{mt}$, ins: mutant, insulin-treated; mt, pl: mutant, placebo-treated

${ }^{*} p<0.05$ for wt, $\mathrm{pl}$ vs mt, $\mathrm{pl}$
Serum C-peptide II and proinsulin concentrations of 21day-old Ins $2^{\mathrm{C} 95 \mathrm{~S}}$ mutant and wild-type mice did not differ (Fig. 2a; proinsulin: wild-type $8.0 \pm 1.5 \mathrm{pmol} / \mathrm{l}$, heterozygous: $8.2 \pm 2.0 \mathrm{pmol} / \mathrm{l}$, homozygous: $4.8 \pm 0.5 \mathrm{pmol} / \mathrm{l})$. These findings show that proinsulin is processed and that mutant insulin/C-peptide II may be secreted.

In order to investigate the influence of diabetes treatment on beta cell function, C-peptide levels were determined. Serum C-peptide levels of heterozygous insulin-treated Ins $2^{\text {C95S }}$ mutant mice were significantly lower than those of wild-type mice and placebo-treated mutants. Placebotreated mutant mice exhibited about half the randomly fed C-peptide concentrations compared with wild-type mice (Fig. 2d, Table 2). AVE2268-treated mutants displayed slightly lower randomly fed C-peptide concentrations than wild-type mice and significantly higher C-peptide levels than insulin-treated $\operatorname{Ins} 2^{\mathrm{C} 95 \mathrm{~S}}$ mice (ESM Fig. 1d). Ten minutes after oral glucose application, serum C-peptide levels of wild-type mice increased 1.5- to 3.6-fold, whereas those of insulin-, AVE2268- and placebo-treated mutants did not rise (Fig. 2e, ESM Fig. 1e, Table 2).

Proinsulin concentrations in the serum of 100-dayold insulin- and placebo-treated $\operatorname{Ins} 2^{\mathrm{C} 95 \mathrm{~S}}$ mutant mice were not detectable; in wild-type mice proinsulin was $14.1 \pm 3.5 \mathrm{pmol} / 1$.

At the age of 100 days, serum glucagon levels of insulintreated mutants and wild-type mice were similar. Placebotreated Ins $2^{\mathrm{C} 95 \mathrm{~S}}$ mutant mice demonstrated significantly higher serum glucagon levels than insulin-treated mutants and wild-type mice (Fig. 2f). These results show that insulin treatment normalised hyperglucagonaemia of Munich Ins $2^{\text {C95S }}$ mutant mice.

Pancreatic C-peptide-, C-peptide II- and proinsulin-toprotein ratios In order to investigate the influence of the Ins $2^{\mathrm{C} 95 \mathrm{~S}}$ mutation on insulin biogenesis, pancreatic proinsulin, C-peptide, and C-peptide II concentrations were determined. Twenty-one-day-old homozygous Munich Ins $2^{\text {C95S }}$ mutant mice demonstrated significantly lower pancreatic C-peptide II- and proinsulin-to-protein-ratios than heterozygous mutants and wild-type mice (Fig. 2b,c). The influence of mutant Ins $2^{\text {C95S }}$ on C-peptide II production was initially more pronounced than the influence on insulin secretion (Fig. 2a).

The pancreatic C-peptide- and proinsulin-to-protein ratios of 100-day-old insulin-treated $I n s 2^{\mathrm{C} 95 \mathrm{~S}}$ mutant mice were significantly lower than those of wild-type mice, but significantly (fourfold) higher than those of placebo-treated mutants (Fig. 2g, h).

Intraperitoneal insulin and placebo-ITT ITTs were performed in order to analyse the effects of diabetes treatment on insulin sensitivity in $I n s 2^{\mathrm{C} 95 \mathrm{~S}}$ mutant mice. At the age of 


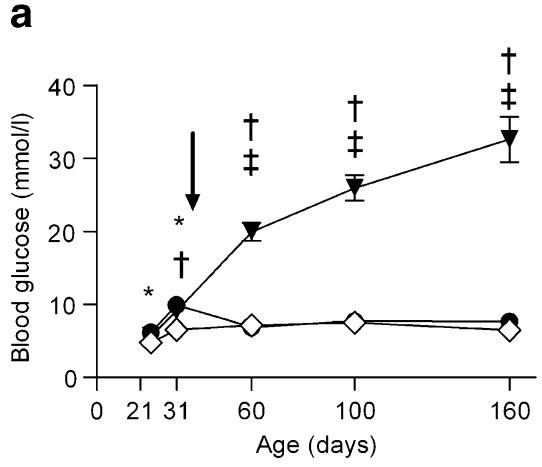

Fig. 1 Blood glucose and oral glucose tolerance. a from 60 days of age onwards, insulin-treated mutants (black circles, $n=11$ ) show similar randomly fed blood glucose concentrations to wild-type mice (white diamonds, $n=12$ ). Placebo-treated mutant mice (black triangles, $n=9$ ) demonstrate a progressive diabetic phenotype. The arrow indicates the beginning of insulin treatment (32 days). b In OGTTs, the AUC for insulin-treated mutants ( $\mathrm{mt}$, ins; hatched bars) is similar to that of wild-type mice (wt, pl; white bars), whereas the AUC for placebo-treated mutants ( $\mathrm{mt}, \mathrm{pl}$; black bars) is significantly increased compared with insulin-treated mutants and wild-type mice, irrespec-

50 days, the AUC for blood glucose in insulin- and placebo-treated mutants and wild-type mice was similar (data not shown). At 100 and 150 days, insulin-treated mutants exhibited a similar blood glucose AUC to wildtype mice, whereas placebo-treated mutants demonstrated a higher AUC than wild-type mice and insulin-treated mutants, indicating insulin resistance (Fig. 3a). Treatment with the SGLT2 inhibitor AVE2268 also normalised insulin sensitivity of Ins $2^{\mathrm{C} 95 \mathrm{~S}}$ mutant mice (ESM Fig. 1f). To investigate the influence of the insulin pellets during the ITT, the blood glucose AUC of a placebo-ITT was compared with that of the ITT at the age of 150 days. The AUC of blood glucose in placebo-treated Ins $2^{\mathrm{C} 95 \mathrm{~S}}$ mutant mice was similar during placebo-ITT and ITT, whereas insulin-treated mutants and wild-type mice demonstrated a significantly larger AUC during placebo-ITT vs ITT (Fig. 3b). The results of ITTs demonstrate that diabetes therapy with both insulin and the SGLT2 inhibitor completely prevented insulin resistance in Munich $\mathrm{Ins} 2^{\mathrm{C} 95 \mathrm{~S}}$ mutant mice, whereas placebo-treated mutants developed insulin resistance at 100 days of age.

Serum lipid peroxidation Serum malondialdehyde (MDA), a biomarker for oxidative stress, was determined in order to investigate the influence of hyperglycaemia and normalisation of blood glucose levels by insulin treatment on oxidative stress. One hundred- and 140-day-old insulintreated Munich Ins $2^{\mathrm{C} 95 \mathrm{~S}}$ mutant mice demonstrated similar serum lipid peroxidation (MDA levels) to age-matched wild-type mice. MDA levels of placebo-treated mutants were over threefold higher than those of insulin-treated mutants and wild-type mice (Fig. 3c). Serum MDA levels

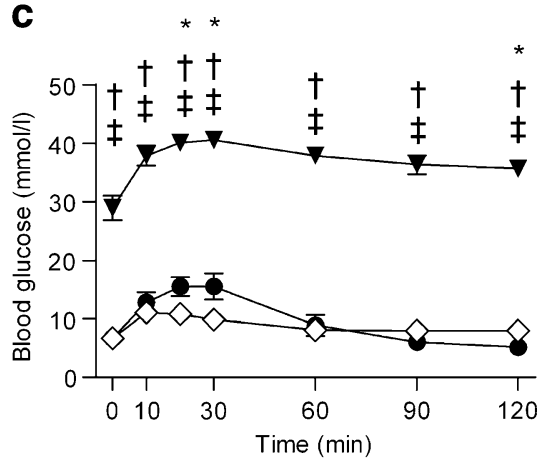

tive of age at testing; age is $45,85,100$ and 150 days (from left to right bar) for each genetic/treatment group. c At 150 days, placebotreated mutant mice (black triangles, $n=9$ ) demonstrate elevated blood glucose levels at all time points of the OGTT, blood glucose concentrations of insulin-treated mutants (black circles, $n=11$ ) decline later than those of wild-type mice (white diamonds, $n=12$ ), but earlier than those of placebo-treated mutants. Data are means \pm SEM; ${ }^{*} p<$ 0.05 for wild-type placebo vs mutant insulin; ${ }^{\dagger} p<0.05$ for wild-type placebo vs mutant placebo; ${ }^{\ddagger} p<0.05$ for mutant insulin vs mutant placebo

of 100-day-old AVE2268-treated Ins $2^{\mathrm{C} 95 \mathrm{~S}}$ mutants were significantly lower than those of placebo-treated mutants but were significantly higher than those of insulin-treated mutants and wild-type mice (ESM Fig. 1g). Blood glucose concentrations correlated with lipid peroxidation in the serum at 100 (ESM Fig. 1h) and 140 days of age (Fig. 3d). These results clearly show that diabetes therapy with insulin prevented oxidative stress in Ins $2^{\mathrm{C} 95 \mathrm{~S}}$ mutant mice.

Western blot analyses of isolated islets Islets of 18-day-old mutants and wild-type mice were morphologically indistinguishable, and the purity ( $~ 95 \%$ islets) and number of islets isolated per animal did not differ between the genetic groups (on average, $101 \pm 23$ islets and $106 \pm 25$ islets were harvested per wild-type and mutant mouse, respectively). The level of BiP and P-eIF $2 \alpha$ expression in the islets of 18day-old Munich Ins $2^{\mathrm{C} 95 \mathrm{~S}}$ mutants was significantly higher than that of wild-type mice (Fig. 3e, f). CHOP (Fig. 3g) and PCNA abundance did not differ (data not shown), and cleaved caspase 3 was not detectable in the islets of 18-dayold mutants and wild-type mice (data not shown).

Qualitative histological findings in the pancreas Insulintreated Munich Ins $2^{\mathrm{C} 95 \mathrm{~S}}$ mutant mice showed fewer insulin positive cells, some with unchanged and some with weaker staining intensity compared with wild-type mice. Placebotreated mutants demonstrated very few, overall weakly stained, insulin positive cells, indicating degranulation of beta cells. Immunohistochemistry for glucagon, somatostatin and pancreatic polypeptide containing non-beta cells revealed an altered islet composition in placebo-treated mutants (Fig. 4). 
a

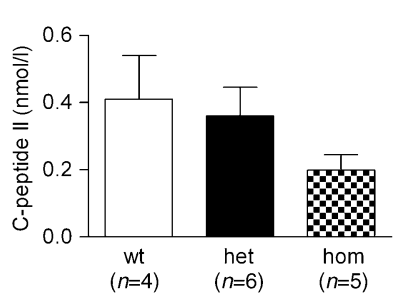

C

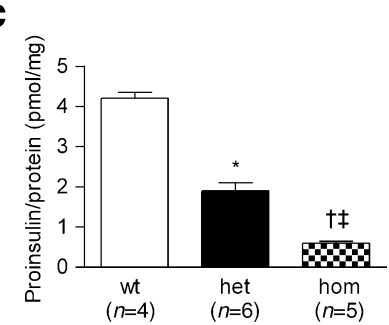

e

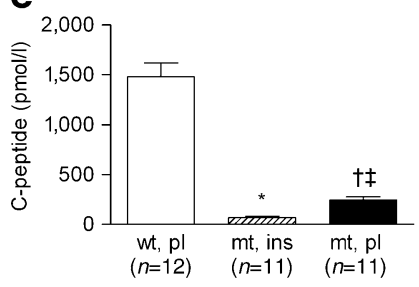

g

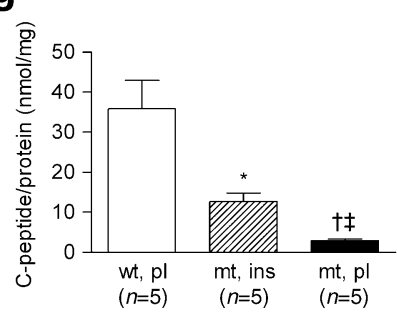

b

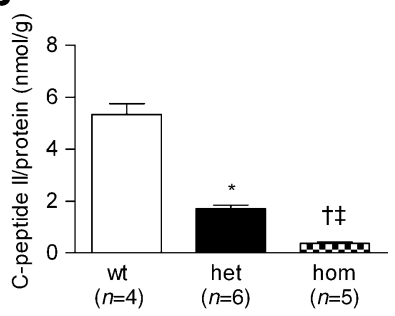

d

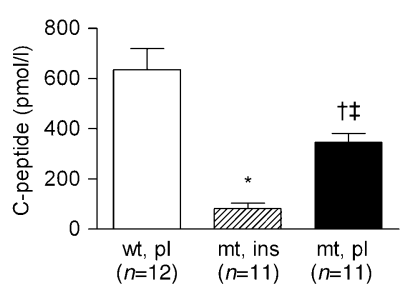

f

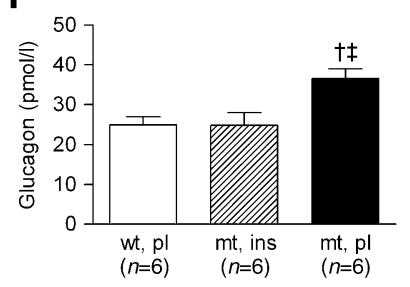

h

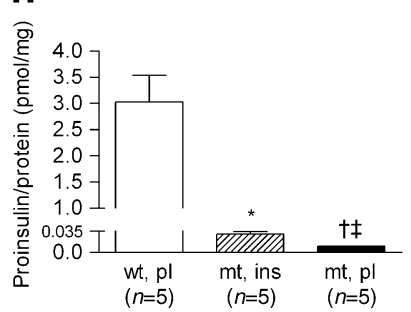

Fig. 2 Pancreatic hormones; serum C-peptide II concentrations (a), pancreatic C-peptide II- (b) and proinsulin-to-protein-ratios (c) of heterozygous (het, black bars) and homozygous (hom, checked bars) mutants and wild-type (wt, white bars) mice at 21 days of age. There is a significant dose-dependent effect of mutant Ins 2 expression on pancreatic C-peptide II and proinsulin content. Randomly fed serum C-peptide (d), C-peptide 10 min after glucose challenge (e), randomly fed glucagon levels (f), pancreatic C-peptide (g) and proinsulin content (h) of 100-day-old wild-type mice (wt, pl), insulin-treated (mt, ins) and placebo-treated (mt, pl) Munich Ins $2^{\mathrm{C} 95 \mathrm{~S}}$ mutant mice. Data are means \pm SEM; in $\mathbf{a}-\mathbf{c}$ : ${ }^{*} p<0.05$ for wt vs het; ${ }^{\dagger} p<0.05$ for wt vs hom; ${ }^{\ddagger} p<0.05$ for het vs hom; in $\mathbf{d}-\mathbf{h}$ : ${ }^{*} p<0.05$ for wt, pl vs mt, ins; ${ }^{\dagger} p<0.05$ for wt, pl vs mt, $\mathrm{pl} ;{ }^{\star} p<0.05$ for $\mathrm{mt}$, ins vs mt, pl

Quantitative stereological findings of the pancreas The pancreas weight of insulin-treated mutants, placebo-treated mutants and wild-type mice was similar $(308 \pm 17,328 \pm 31$, and $326 \pm 19 \mathrm{mg}$, respectively). Insulin-treated mutants demonstrated slightly higher total islet volumes (Fig. 5a) as well as significantly higher total beta cell volumes (Fig. 5b) and total volumes of isolated beta cells in the pancreas (Fig. 5c) compared with placebo-treated mutants,

whereas these variables were significantly lower than in wild-type mice. Insulin-treated mutants and wild-type mice exhibited a similar total volume of non-beta cells in the islets (Fig. 5d), whereas the total volume of non-beta cells was significantly increased in placebo-treated mutants. The numerical fraction of replicating and apoptotic beta cells and non-beta cells in the islets varied substantially within one group and was not significantly different between groups (Table 3).

The quantitative stereological findings demonstrate that insulin treatment ameliorates beta cell loss as well as islet neogenesis and normalises diabetes-induced non-beta cell hyperplasia in Munich $\operatorname{Ins} 2^{\mathrm{C} 95 \mathrm{~S}}$ mutant mice.

\section{Discussion}

Patients exhibiting heterozygous INS mutations develop diabetes mostly before 6 months of age because of dominant negative effects of the mutated INS allele [2, 4, $7,17]$. Mutations that affect pre-proinsulin processing and proinsulin folding lead to the accumulation of mutant protein in the ER and inefficient secretion of both mutant and native insulin. The induction of the unfolded protein response attenuates protein synthesis and may result in apoptosis of beta cells with time [7]. At the time of presentation, many patients exhibit greatly elevated blood glucose levels and therefore probably start insulin therapy at an advanced disease stage [4]. Male Munich $\operatorname{Ins} 2^{\text {C95S }}$ mutant mice develop severe diabetes mellitus, insulin resistance, hypoinsulinaemia and beta cell loss [10] and

Table 2 Serum C-peptide concentrations (pmol/1)

\begin{tabular}{lllll}
\hline Time & Group $(n \geq 7)$ & \multicolumn{1}{l}{ Age (days) } & \\
\cline { 3 - 5 } & & 45 & 85 & 150 \\
\hline$t 0$ & wt, pl & $827 \pm 140$ & $639 \pm 301$ & $525 \pm 237$ \\
& mt, ins & $156 \pm 105^{*}$ & $126 \pm 49^{*}$ & $161 \pm 107^{*}$ \\
& mt, pl & $473 \pm 145^{\dagger *}$ & $328 \pm 61^{\dagger+}$ & $247 \pm 93^{\dagger}$ \\
$t 10$ & wt, pl & $1225 \pm 458$ & $1576 \pm 340$ & $1870 \pm 307$ \\
& mt, ins & $113 \pm 62^{*}$ & $93 \pm 50^{*}$ & $147 \pm 79^{*}$ \\
& mt, pl & $295 \pm 61^{\dagger \dagger}$ & $291 \pm 96^{\dagger \dagger}$ & $257 \pm 87^{\dagger+}$ \\
\hline
\end{tabular}

Data are means \pm SD

Randomly fed $(t 0)$ and $10 \mathrm{~min}(t 10)$ after oral glucose application; Cpeptide levels of insulin-treated (mt, ins) and placebo-treated mutants $(\mathrm{mt}, \mathrm{pl})$ are lower than those of wild-type mice (wt, $\mathrm{pl}$ ), and insulintreated mutants exhibit lower C-peptide levels than placebo-treated mutants. In contrast to wild-type mice, C-peptide levels of mutants do not increase after glucose challenge

${ }^{*} p<0.05$ for wt, $\mathrm{pl}$ vs mt, ins; ${ }^{\dagger} p<0.05$ for wt, $\mathrm{pl}$ vs mt, $\mathrm{pl} ;{ }^{\star} p<0.05$ for $\mathrm{mt}$, ins vs $\mathrm{mt}$, pl 


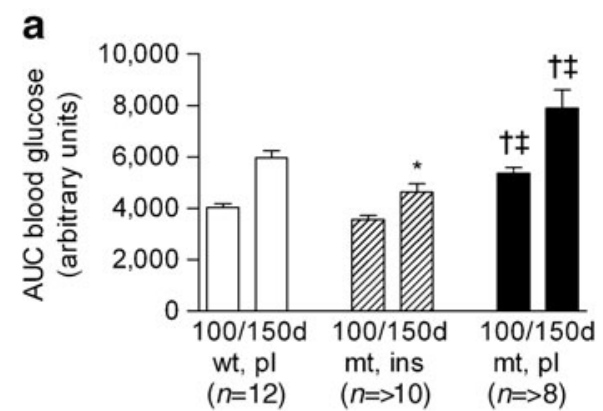

C

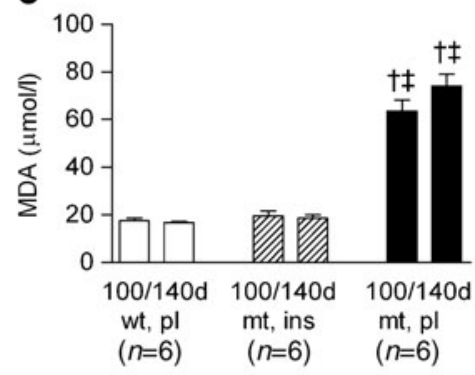

b

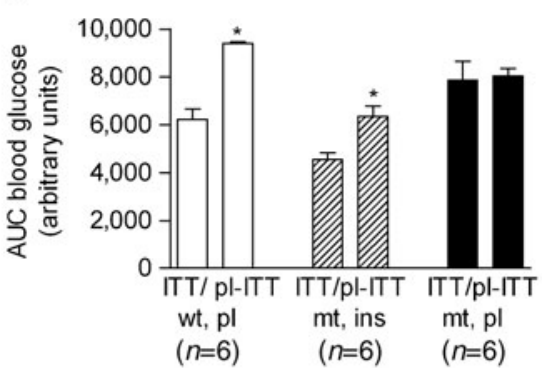

d

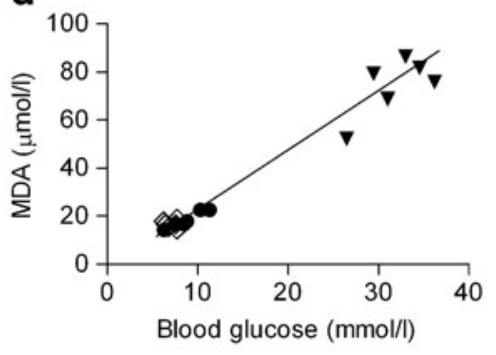

e

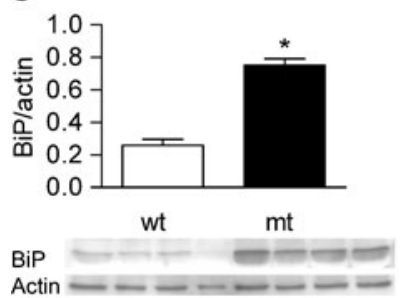

f

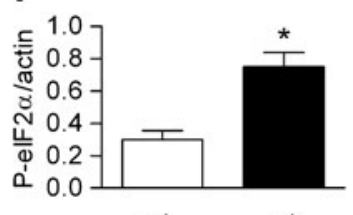

wt

P-elF2 $\alpha$

Actin g

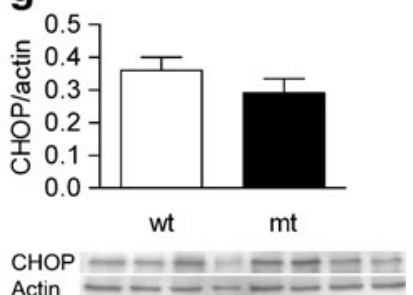

Fig. 3 Insulin tolerance, serum lipid peroxidation and ER stress in isolated islets; a,b Insulin tolerance tests at 100 and 150 days of age (a) and comparison of insulin (ITT) and placebo-insulin tolerance test (pl-ITT) at 150 days of age (b). One hundred- and 150-day-old placebo-treated mutants (mt, pl) demonstrate a significantly higher blood glucose AUC in the ITT compared with wild-type mice (wt, pl) and insulin-treated mutants (mt, ins) (a). The blood glucose AUC in insulin-treated mutants ( $\mathrm{mt}$, ins) and wild-type mice is significantly lower after insulin injection (ITT, left bar) than after administration of $0.9 \%$ (wt/vol.) $\mathrm{NaCl}$ (pl-ITT, right bar). Placebo-treated mutant mice show a similar AUC in the ITT and the placebo-ITT (b). c, d Oxidative stress in serum at 100 and 140 days of age. Serum MDA equivalents (c) are significantly elevated in placebo-treated Munich
Ins $2^{\mathrm{C} 95 \mathrm{~S}}$ mutants $(\mathrm{mt}, \mathrm{pl})$ and normalised in insulin-treated mutants (mt, ins) vs wild-type mice (wt, pl) at 100 and 140 days of age. Blood glucose concentrations and serum MDA equivalents of 140-day-old animals correlate by $r^{2}=0.975(p<0.0001)$; insulin-treated mutants, black circles; wild-type mice, white diamonds; placebo-treated mutant mice, black triangles (d). e- - ER stress proteins in isolated islets. Eighteen-day-old mutants ( $\mathrm{mt}, n=8)$ show an increased abundance of $\mathrm{BiP}$ (e) and P-eIF $2 \alpha$ protein (f) and an unchanged abundance of CHOP in islets (g) compared with wild-type mice (wt, $n=8$ ). Data are means \pm SEM; in a and $\mathbf{c}:{ }^{*} p<0.05$ for wt, $\mathrm{pl}$ vs $\mathrm{mt}$, ins; ${ }^{\dagger} p<0.05$ for wt, pl vs mt, pl; ${ }^{\star} p<0.05$ for mt, ins vs mt, pl; in $\mathbf{b}:{ }^{*} p<0.05$ for ITT vs placebo-ITT; in e-g: ${ }^{*} p<0.05$ for 18 -day-old mt vs wt mice

in vitro studies that demonstrated that mutant proinsulin missing the A6-A11 intrachain disulfide bond is partially effectively secreted from $293 \mathrm{~T}$ cells [18]. In contrast, another in vitro study using cells expressing the proinsulin mutant $\mathrm{C}^{\mathrm{A} 6} \mathrm{Y}$ demonstrated almost no secretion of mutant proinsulin [4], similarly to proinsulin bearing the Akita mutation $\left(\mathrm{C}^{\mathrm{A} 7} \mathrm{Y}\right)[18]$ and several other mutant insulin types that also perturb the secretion of native insulin [7-9]. However, pancreatic C-peptide II content was significantly reduced in $I n s 2^{\mathrm{C} 95 \mathrm{~S}}$ mutants, showing that early toxic effects of mutant Ins $2^{\mathrm{C} 95 \mathrm{~S}}$ pertained to proinsulin produc- 

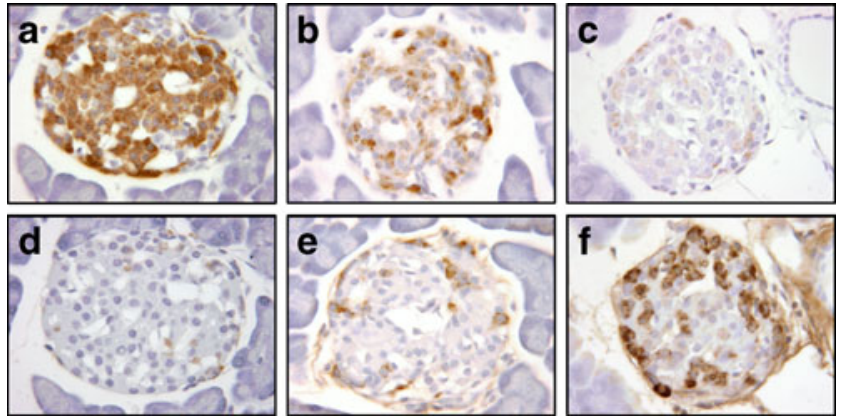

Fig. 4 Qualitative histological findings of islets at 160 days of age; immunohistochemical staining for insulin-producing beta cells $(\mathbf{a}-\mathbf{c})$, and for glucagon, somatostatin and pancreatic polypeptide producing non-beta cells $(\mathbf{d}-\mathbf{f})$. Wild-type mice show normal islet architecture mainly consisting of strongly stained beta cells (a) and few non-beta cells (d), mostly located at the periphery of the islet. Insulin-treated mutants show strongly and weakly stained beta cells (b) and few nonbeta cells, located at the periphery of the islets (e), whereas placebotreated mutants demonstrate only few, weakly insulin positive islet-cells (c) and non-beta cells are distributed throughout the islet profile (f)

tion/degradation. These dominant negative effects of mutated Ins2 may be explained by the recruitment of nonmutant proinsulin into disulfide-linked complexes, leading to blocking of insulin production and subsequent insulin deficiency [19]. The induction of the unfolded protein response also negatively affects the synthesis and secretion of wild-type insulin as a result of translational inhibition [7, 9]. The induction of the unfolded protein response in Munich Ins $2^{\mathrm{C} 95 \mathrm{~S}}$ mutants was analysed in the present study using western blot analyses of isolated islets of mutants and wild-type mice. Before the onset of hyperglycaemia, Ins $2^{\mathrm{C} 95 \mathrm{~S}}$ mutants demonstrated an increased abundance of the chaperone $\mathrm{BiP}$, which increases protein folding activity and prevents protein aggregation, and of P-eIF $2 \alpha$, which plays a role in the prevention of accumulation of unfolded proteins by translational inhibition [20]. These findings are in line with the results of other studies that demonstrated increased ER stress in response to the expression of mutated insulin $[4,21,22]$. The abundance of the apoptosis markers CHOP and cleaved caspase 3, as well as PCNA, an indicator for cell replication, was unaltered in young Ins $2^{\mathrm{C} 95 \mathrm{~S}}$ mutants, which was not unexpected, since islet mass only starts to decline after 100 days of age in untreated mutants (N. Herbach, E. Wolf and R. Wanke, unpublished data). Cells expressing the mutant proinsulin $\mathrm{C}^{\mathrm{A} 6} \mathrm{Y}$ exhibited increased expression of ER stress markers, and apoptosis was more frequent in vitro [4]. Therefore, toxic gain of function might perturb beta cell viability in INS mutation carriers [4] and in Ins $2^{\mathrm{C} 95 \mathrm{~S}}$ mutants in later stages of the disease. Unfortunately, it was not possible to isolate sufficient quantities of pure islets after onset of hyperglycaemia despite insulin treatment, as a result of the extreme fragility and altered morphology of the islets of mutant mice. Therefore, western blot analyses of islets of insulin- and placebo-treated mutants were not feasible (N. Herbach, S. Kautz and R. Wanke, unpublished observations); however, early insulin therapy of $\operatorname{Ins} 2^{\mathrm{C} 95 \mathrm{~S}}$ mutants might, in addition to reducing oxidative stress, reduce ER stress by reducing insulin demand and production [23].

Diabetes therapy in heterozygous mutants was shown to normalise (insulin) or greatly reduce (AVE2268) blood glucose concentrations, thereby preventing the development of insulin resistance and oxidative stress in heterozygous male Ins $2^{\mathrm{C} 95 \mathrm{~S}}$ mutant mice. C-peptide secretion, however, was suppressed by insulin therapy. Likewise, in insulintreated patients exhibiting INS mutations leading to PNDM, C-peptide levels declined and were soon undetectable [4]. The effects of chronic insulin therapy on insulin production and secretion remain controversial. Both negative feedback and stimulatory effects of insulin on insulin secretion and INS expression have been observed, probably depending on the system studied and the dosage used [23-25], whereas the results of the present study indicate the reduction of Cpeptide secretion in response to the application of physiological doses of insulin in vivo.

The pancreatic C-peptide content of insulin-treated mutants was significantly higher than that of placebotreated Ins $2^{\mathrm{C} 95 \mathrm{~S}}$ mutant mice. Therefore, the prevention of glucotoxicity and oxidative stress ameliorated signs of beta cell exhaustion and increased insulin storage, which is most likely attributable to reduced insulin secretion/demand [25]. The severe reduction of pancreatic C-peptide and proinsulin levels in placebo-treated mutants argues for increased
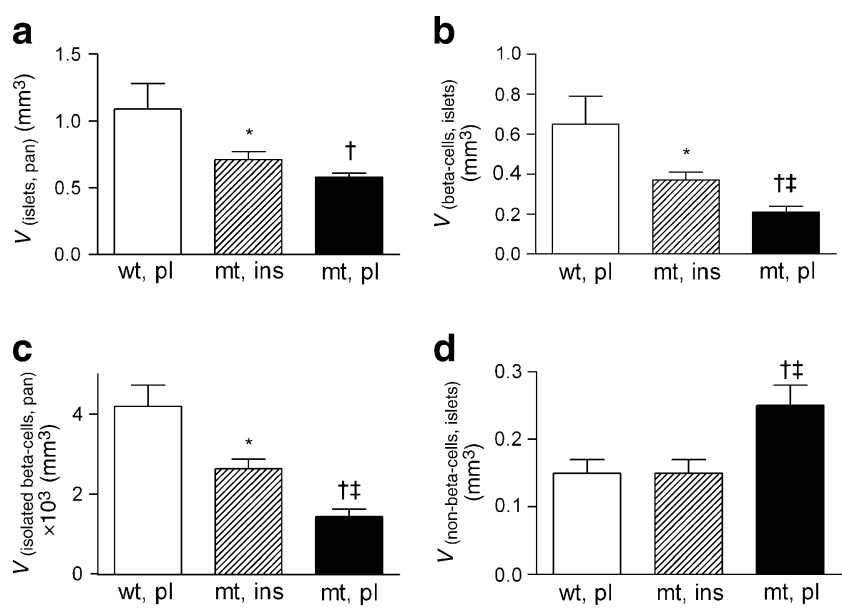

Fig. 5 Quantitative stereological findings for pancreases at the age of 160 days: (a) total islet $\left(V_{\text {(islets, pan) }}\right),(\mathbf{b})$ beta cell $\left(V_{\text {(beta cells, islets) }}\right),(\mathbf{c})$ isolated beta cell $\left(V_{\text {(isolated beta cells, pan) }}\right)$ and (d) non-beta cell volumes $\left(V_{\text {(non-beta cells, islets) }}\right)$ of insulin- (mt, ins, $\left.n=4\right)$ and placebo-treated $(\mathrm{mt}$, $\mathrm{pl}, n=4)$ Munich Ins $2^{\mathrm{C} 95 \mathrm{~S}}$ mutants and wild-type (wt, pl, $\left.n=4\right)$ mice. The total beta cell and isolated beta cell volume of insulin-treated mutants is significantly higher and the total non-beta cell volume is normalised vs placebo-treated mutants. Data are means \pm SEM; ${ }^{*} p<$ 0.05 for wt, $\mathrm{pl}$ vs mt, ins; ${ }^{\dagger} p<0.05$ for wt, $\mathrm{pl} \mathrm{vs} \mathrm{mt,} \mathrm{pl} ;{ }^{\ddagger} p<0.05$ for mt, ins vs $\mathrm{mt}, \mathrm{pl}$ 
Table 3 Apoptotic and replicating beta cells and non-beta cells

\begin{tabular}{lcccc}
\hline Group $(n \geq 7)$ & $\begin{array}{l}\text { TUNEL-positive } \\
\text { beta cell nuclei }\end{array}$ & $\begin{array}{l}\text { BrdU-positive } \\
\text { beta cell nuclei }\end{array}$ & $\begin{array}{l}\text { TUNEL-positive } \\
\text { non-beta cell nuclei }\end{array}$ & $\begin{array}{l}\text { BrdU-positive } \\
\text { non-beta cell nuclei }\end{array}$ \\
\hline wt, pl & $25 \pm 18$ & $109 \pm 45$ & $21 \pm 7$ & $30 \pm 6$ \\
$\mathrm{mt}$, ins & $23 \pm 26$ & $105 \pm 31$ & $27 \pm 8$ & $37 \pm 24$ \\
$\mathrm{mt}, \mathrm{pl}$ & $20 \pm 40$ & $160 \pm 33$ & $31 \pm 1$ & $54 \pm 29$ \\
\hline
\end{tabular}

Data are number of positive nuclei per 100,000 cells and are expressed as mean \pm SD

wt, pl: wild-type, placebo-treated; mt, ins: mutant, insulin-treated; $\mathrm{mt}, \mathrm{pl}$ : mutant, placebo-treated

intracellular degradation of proinsulin. Likewise, increased intracellular degradation of mutant proinsulin was found in the beta cells of Akita mice, leading to reduced insulin and C-peptide content in the pancreas [22, 26, 27].

Insulin treatment inhibited non-beta cell hyperplasia, preserved islet architecture and normalised hyperglucagonaemia in $\operatorname{Ins} 2^{\mathrm{C} 95 \mathrm{~S}}$ mutant mice. Chronically elevated blood glucose levels can lead to disturbed glucose sensing in alpha-cells, resulting in increased glucagon secretion, thereby impairing the diabetic phenotype, a phenomenon that is also observed in human diabetic patients [28-30].

Insulin treatment ameliorated beta cell loss in male Ins $2^{\mathrm{C} 95 \mathrm{~S}}$ mutants, which can be explained by the prevention of oxidative stress/glucotoxicity [31, 32]. In addition, downregulation of the insulin biosynthetic process by exogenous insulin may prevent an exaggerated unfolded protein response, beta cell apoptosis and increased production of ROS. It was suggested that misfolded proteins compromise beta cell function and lead to decreased insulin secretion, whereas the insulin production of functional beta cells is stimulated, eventually leading to beta cell failure and onset of diabetes [8]. Increased insulin production of the beta cell also leads to increased production of ROS, and chronically elevated ROS negatively influences beta cell function and survival [6]. However, beta cell mass was not completely preserved in insulin-treated $\operatorname{Ins} 2^{\mathrm{C} 95 \mathrm{~S}}$ mutants, which may be due to the inability of exogenous insulin to normalise ER stress. The number of apoptotic beta cells in histological sections was not increased in mutant vs wildtype mice, which is in line with our previous investigations [10] and may be explained by the late time point of investigation, where beta cell mass is already reduced by about $70 \%$ and by the rapid clearance of apoptotic cells by macrophages [27, 33, 34]. However, the reduction of the beta cell mass suggests that apoptosis does occur in Ins $2^{\mathrm{C} 95 \mathrm{~S}}$ mutants, since this variable, unlike apoptotic cell counts, provides a long-term readout and not just a snapshot of the situation.

Taken together, the present data obtained from insulintreated Ins $2^{\mathrm{C} 95 \mathrm{~S}}$ mutants could show that early diabetes treatment ameliorates beta cell loss and prevents oxidative stress, insulin resistance and non-beta cell hyperplasia, as well as alpha cell hyperfunction, suggesting that early insulin treatment may be beneficial in human carriers of INS mutations. Novel therapeutic approaches that ameliorate cellular stress resulting from the synthesis of mutant insulin could, however, possibly restore beta cell function, thereby enabling the secretion of native insulin, which could be sufficient to maintain normal glucose homeostasis in heterozygous mutation carriers.

Acknowledgements We would like to thank L. Pichl, A. Siebert, A. Ciolovan and S. Zwirz for excellent technical assistance. Special thanks to sanofi-aventis Deutschland $\mathrm{GmbH}$, particularly D. Isert and A. Herling for kindly providing the SGLT2 inhibitor AVE2268, as well as comprehensive support in designing the SGLT2 inhibitor treatment protocol. This study was supported by the Deutsche Forschungsgemeinschaft (GRK 1029; S. Kautz, L. van Bürck, M. Schuster, N. Herbach, R. Wanke).

Contribution statement SK contributed to the analysis and interpretation of data, drafting the article and gave final approval for the article. LvB and MS contributed to the analysis of data, and revision of the article, and gave final approval for the article. EW and RW contributed to the conception and design, and revision of the article, and gave final approval for the article. NH contributed to the conception and design, analysis and interpretation of data, drafting the article, and gave final approval for the article.

Duality of interest The authors declare that there is no duality of interest associated with this manuscript.

\section{References}

1. Greeley SA, Tucker SE, Naylor RN, Bell GI, Philipson LH (2010) Neonatal diabetes mellitus: a model for personalized medicine. Trends Endocrinol Metab 21:464-472

2. Edghill EL, Flanagan SE, Patch AM et al (2008) Insulin mutation screening in 1,044 patients with diabetes: mutations in the INS gene are a common cause of neonatal diabetes but a rare cause of diabetes diagnosed in childhood or adulthood. Diabetes 57:1034 1042

3. Meur G, Simon A, Harun N et al (2010) Insulin gene mutations resulting in early-onset diabetes: marked differences in clinical presentation, metabolic status, and pathogenic effect through endoplasmic reticulum retention. Diabetes 59:653-661

4. Colombo C, Porzio O, Liu M et al (2008) Seven mutations in the human insulin gene linked to permanent neonatal/infancy-onset diabetes mellitus. J Clin Invest 118:2148-2156 
5. Garin I, Edghill EL, Akerman I et al (2010) Recessive mutations in the INS gene result in neonatal diabetes through reduced insulin biosynthesis. Proc Natl Acad Sci U S A 107:3105-3110

6. Steiner DF, Park SY, Stoy J, Philipson LH, Bell GI (2009) A brief perspective on insulin production. Diabetes Obes Metab 11(Suppl 4):189-196

7. Stoy J, Steiner DF, Park SY, Ye H, Philipson LH, Bell GI (2010) Clinical and molecular genetics of neonatal diabetes due to mutations in the insulin gene. Rev Endocr Metab Disord 11:205-215

8. Park SY, Ye H, Steiner DF, Bell GI (2010) Mutant proinsulin proteins associated with neonatal diabetes are retained in the endoplasmic reticulum and not efficiently secreted. Biochem Biophys Res Commun 391:1449-1454

9. Rajan S, Eames SC, Park SY et al (2010) In vitro processing and secretion of mutant insulin proteins that cause permanent neonatal diabetes. Am J Physiol Endocrinol Metab 298:E403-E410

10. Herbach N, Rathkolb B, Kemter E et al (2007) Dominant-negative effects of a novel mutated Ins2 allele causes early-onset diabetes and severe beta-cell loss in Munich Ins2C95S mutant mice. Diabetes 56:1268-1276

11. Aigner B, Rathkolb B, Herbach N, de Angelis MH, Wanke R, Wolf E (2008) Diabetes models by screen for hyperglycemia in phenotype-driven ENU mouse mutagenesis projects. Am J Physiol Endocrinol Metab 294:E232-E240

12. Bickel M, Brummerhop H, Frick W et al (2008) Effects of AVE2268, a substituted glycopyranoside, on urinary glucose excretion and blood glucose in mice and rats. Arzneimittelforschung 58:574-580

13. van Burck L, Blutke A, Kautz S et al (2010) Phenotypic and pathomorphological characteristics of a novel mutant mouse model for maturity-onset diabetes of the young type 2 (MODY 2). Am J Physiol Endocrinol Metab 298:E512-E523

14. Pamir N, Lynn FC, Buchan AM et al (2003) Glucose-dependent insulinotropic polypeptide receptor null mice exhibit compensatory changes in the enteroinsular axis. Am J Physiol Endocrinol Metab 284:E931-E939

15. Herbach N, Goeke B, Schneider M, Hermanns W, Wolf E, Wanke $\mathrm{R}$ (2005) Overexpression of a dominant negative GIP receptor in transgenic mice results in disturbed postnatal pancreatic islet and beta-cell development. Regul Pept 125:103-117

16. Wanke R, Weis S, Kluge D et al (1994) Morphometric evaluation of the pancreas of growth hormone-transgenic mice. Acta Stereologica $13: 3-8$

17. Liu M, Hodish I, Haataja L et al (2010) Proinsulin misfolding and diabetes: mutant INS gene-induced diabetes of youth. Trends Endocrinol Metab 21:652-659

18. Liu M, Li Y, Cavener D, Arvan P (2005) Proinsulin disulfide maturation and misfolding in the endoplasmic reticulum. J Biol Chem 280:13209-13212
19. Liu M, Haataja L, Wright J et al (2010) Mutant INS-gene induced diabetes of youth: proinsulin cysteine residues impose dominantnegative inhibition on wild-type proinsulin transport. PLoS One 5: e13333

20. Araki E, Oyadomari S, Mori M (2003) Impact of endoplasmic reticulum stress pathway on pancreatic beta-cells and diabetes mellitus. Exp Biol Med (Maywood) 228:1213-1217

21. Oyadomari S, Koizumi A, Takeda K et al (2002) Targeted disruption of the Chop gene delays endoplasmic reticulum stress-mediated diabetes. J Clin Invest 109:525-532

22. Allen JR, Nguyen LX, Sargent KE, Lipson KL, Hackett A, Urano F (2004) High ER stress in beta-cells stimulates intracellular degradation of misfolded insulin. Biochem Biophys Res Commun 324:166-170

23. Xu GG, Gao ZY, Borge PD Jr, Jegier PA, Young RA, Wolf BA (2000) Insulin regulation of beta-cell function involves a feedback loop on SERCA gene expression, $\mathrm{Ca}(2+)$ homeostasis, and insulin expression and secretion. Biochemistry 39:14912-14919

24. Melloul D, Marshak S, Cerasi E (2002) Regulation of insulin gene transcription. Diabetologia 45:309-326

25. Rutter GA (1999) Insulin secretion: feed-forward control of insulin biosynthesis? Curr Biol 9:R443-R445

26. Wang J, Takeuchi T, Tanaka S et al (1999) A mutation in the insulin 2 gene induces diabetes with severe pancreatic beta-cell dysfunction in the Mody mouse. J Clin Invest 103:27-37

27. Izumi T, Yokota-Hashimoto H, Zhao S, Wang J, Halban PA, Takeuchi T (2003) Dominant negative pathogenesis by mutant proinsulin in the Akita diabetic mouse. Diabetes 52:409-416

28. Abdul-Ghani M, DeFronzo RA (2007) Fasting hyperglycemia impairs glucose-but not insulin-mediated suppression of glucagon secretion. J Clin Endocrinol Metab 92:1778-1784

29. Dunning BE, Foley JE, Ahren B (2005) Alpha cell function in health and disease: influence of glucagon-like peptide-1. Diabetologia 48:1700-1713

30. Kawamori D, Kulkarni RN (2009) Insulin modulation of glucagon secretion: the role of insulin and other factors in the regulation of glucagon secretion. Islets 1:276-279

31. Kaiser N, Leibowitz G, Nesher R (2003) Glucotoxicity and betacell failure in type 2 diabetes mellitus. J Pediatr Endocrinol Metab 16:5-22

32. Wajchenberg BL (2007) Beta-cell failure in diabetes and preservation by clinical treatment. Endocr Rev 28:187-218

33. Donath MY, Halban PA (2004) Decreased beta-cell mass in diabetes: significance, mechanisms and therapeutic implications. Diabetologia 47:581-589

34. Huerta S, Goulet EJ, Huerta-Yepez S, Livingston EH (2007) Screening and detection of apoptosis. J Surg Res 139:143-156 